Available for free online at https://ojs.hh.se/

JISTG

Journal of Intelligence Studies in Business 2 (2012) 51-58

\title{
Applying patent analysis with Competitive technical intelligence: the case of Plastics
}

\author{
Marisela Rodríguez Salvador and Mario Alberto Tello Bañuelos
}

\author{
Instituto Tecnológico y de Estudios Superiores de Monterrey (ITESM), \\ Campus Monterrey, \\ Eugenio Garza Sada 2501, Monterrey, Mexico \\ marisrod@itesm.mx
}

Received 15 March 2012; received in revised form 30 April 2012; accepted 30 April 2012

\begin{abstract}
This article presents a methodology that integrates patent analysis in a study of Competitive Technical Intelligence. Our approach was applied in the area of plastics. We identified areas of research, leading companies and technology trends.
\end{abstract}

Keywords: Competitive technical intelligence, innovations, patent analysis, plastics, thermoplastic elastomers

\section{Introduction}

The oil crisis of 1974 influenced the increase in consumption of plastics, especially in the automotive industry. Plastics have allowed to decrease the weight of automobiles, which have had a significant impact for example on savings in fuel consumption per kilometer. Among the polymers used to reduce the weight of automobiles are polyesters, polypropylene, polyvinyl chlorides, polyurethanes, polyethylene, ABS (acrylonitrile-butadiene), nylon (Feldman, 2008). Within this area the level of technological development is very fast so it is required to be 
continually on the lookout for events arising in the environment, for example, development of new technologies, materials, etc.

This is the case of thermoplastic elastomers, which are characterized by having the elastic behavior of rubber and thermoplastic processing. In fact it has become the fastest growing segment of the polymer industry, so they are considered a great business opportunity (Kear, 2003).

In Mexico, in the city of Monterrey (state of Nuevo Leon) the main campus of the Instituto Tecnológico y de Estudios Superiores de Monterrey (ITESM) is located. Within this institute the unit of Competitive Technical Intelligence (Center of Quality and Manufacturing) provides training, consultancy and research in that area.

In 2011 a collaborative project between a Mexican company and the ITESM, Campus Monterrey, was implemented. Initially this project was linked to that company, which was interested in the area of thermoplastic elastomers. At the beginning of the project, the topic was focused on alternative monomers to styrene, butadiene and/or isoprene, preferably from renewable sources. The general statistical results of that topic, based on the software Matheo Patent's results, were presented to the company. After that a strong reorganization from the headquarters of the company was made and this company was closed. We decided to continue with our methodology and to undertake a general study on plastic, considering patent analysis in the topics of thermoplastic elastomers and styrene, butadiene and isoprene. The main goal was to identify technology trends that could allow to determine opportunities, including the identification of leading companies and their main areas of research.

\section{Competitive Technical Intelligence and patent analysis}

Competitive intelligence is rooted in three areas: governmental intelligence agencies, management studies and market research (Michaeli, 2006, cited by Schwarz 2007). While it is true that competitive intelligence had its beginnings in the 70s, it was until 1980 when Michael Porter laid the foundations of this discipline in his book Competitive Strategy: Techniques for Analyzing Industries and Competitors.
This discipline denotes an apparent novelty in Latin America, but is widely used by major multinational companies, in 2001, according Downham et al, cited by Medina Lugo (2008), over $82 \%$ of companies with revenues in excess of USD \$10 000 million had an intelligence system, while $60 \%$ of those earning over USD \$1 billion also had some practices of intelligence.

In the mid's 80's in the United States the Strategic and Competitive Intelligence Professionals, SCIP, was established. The organization is a leading professional association dedicated to the study of competitive intelligence in the world. According to SCIP homepage (2011), competitive intelligence is "the process of monitoring the competitive environment and analyze the findings in the context of the problems specific to each company in order to provide support in decisionmaking."

In this context we shall define Competitive Technical Intelligence (CTI), as the process focused on monitoring the competitive and technological environment of an organization, that supports decisions, especially those related to market, innovation, product design, and research and development (R \& D). CTI is carried out in organizations of all sizes through a continuous and systematic process that involves legal and ethical collection of information, analysis relevant conclusions, and the collection and controlled dissemination of useful results. By means of this process it's possible to identify opportunities and threats in the environment for strategic planning processes (Adapted from the SCIP, 2011).

CTI is applicable to various types and sizes of organizations to determine business opportunities, information on specific products and services from competitors, threats, etc.

Innovation can be achieved by CTI. Innovation is commonly defined as the beginning of an idea in relation to a product or process that is new for a specific company. However, innovation is the successful exploitation of new ideas: it therefore requires of two conditions: The novelty and use (Alegre, Chiva \& Lapiedra, 2009). In this context patent data are an important source of competitive intelligence that companies can use to gain strategic advantage (Shih, Liu \& Hsu, 2010). For several years patents have been considered as indicators of technological progress. Through patent analysis it is possible to identify among 
others issues: areas of technological specialization, company profiles, institutions involved in research, technological activity by countries and collaborative networks (Rodríguez, 2003).

Moreover, the usefulness of patents has been demonstrated as a support of strategic planning for products and processes (Lozano, 2003).

In order to carry out the analysis of large volumes of information the field of scientometrics represents a valuable alternative. This is defined as the set of studies to quantify the process of written communication, the nature and evolution of scientific disciplines / technologies by counting and analysis of various characteristics of the communication (Amat, 1994 cited by Rodríguez 2003). Also using analysis of co-occurrence (cooccurrence of words), with advanced techniques such as mapping technology it is possible to identify the behavior of business or technology areas in a specific field and period of time, and thereby identify opportunities and threats to innovation.

Patent information can be found in different databases, some of them are:

- $\quad$ USPTO - Patent Database Full text and images, United States

- ESP@CENET - Database of EPO (European Patent Office)

- Google patent - patent database from USPTO

- PATENTSCOPE - Database of international patent applications WIPO (WIPO)

- DEPATISnet - Database of German Patent

- AJP - Database of the Japan Patent Office

- DWPI - Derwent World Patents Index patent database from Thomson Reuters

The use of specialized software makes patent analysis easier. One of the most recognized software in the field of patents is Matheo Patent from France. Through this program is possible to access USPTO and Espacenet databases and monitor technology. We applied this software in plastics, including thermoplastic elastomers.

In this area the level of technological development is very fast because of events arising in the environment including, development of new technologies, materials, etc.

\section{The case of study}

Thermoplastic elastomers (TPEs) are a class of polymers within their design limits, they behave like thermoset rubber but above its melting point or softening temperature, they could be processed by thermoplastic methods with the advantage that unlike thermoset rubber, TPEs can be easily reworked and remodeled. The ability to transform these materials with thermoplastic methods allows freedom of design and manufacturing that thermoset rubber does not offer (RTP, 2011).

All TPEs are composed of amorphous and crystalline domains. Some of them are mixtures or alloys of crystalline and amorphous polymers; some are block copolymers comprising blocks of crystalline and amorphous domains along the same polymer chain. It is important to mention that the crystalline domains provide to TPEs the character thermoplastic and amorphous domains give them the elastomeric character (RTP, 2011). The crystalline domains are usually known as the phase "hard" and the amorphous domain as phase "soft." Although both phases contributes to the general properties of a physical and mechanical TPE, some key properties may be associated with one stage or another which guides the selection or design of a compound of TPE.

As we have established before TPEs can be processed as thermoplastics imitating the performance of thermoset rubbers, for this reason TPEs have become the category of plastics with the most growth during the last 10 years (Grande, 2008). Among the main drivers of market growth of TPEs are: simplified processing with fewer manufacturing steps, virtual elimination of scrap, considerably shorter cycles, lower power consumption, and lower costs per volume due to the low density of most TPEs (Drobny, 2007). The faster processing and low rates wastes have made TPEs a niche market that continually expand in markets such as automotive, medical and consumer products (Grande, 2008). In this respect, we applied patent analysis in a Competitive Technical Intelligence process as a method to monitor the technology.

\section{Integration approach}

Based on the Competitive Intelligence methodology proposed by Escorsa \& Rodríguez (2000), a synergic model was designed, as shown in figure 1 . 


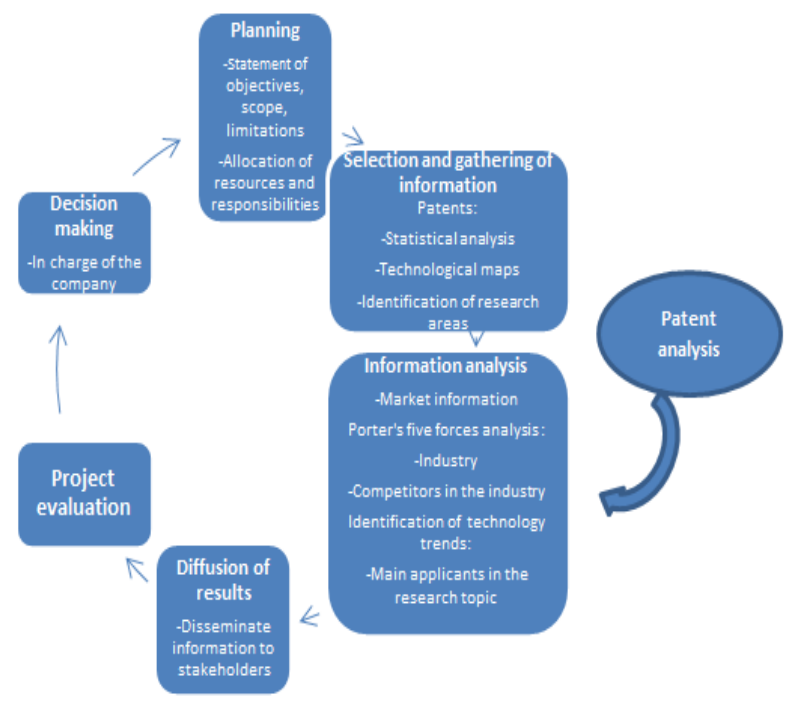

Figure 1. Method of Competitive Technical Intelligence with patent analysis.

The objective was to identify trends through patent analysis within thermoplastic elastomers area.

In the subsequent paragraphs, we present a brief explanation of the development of each step, including insight obtained from the implementation of the method proposed above.

\section{The Methodology}

Even though this study refers to plastics, including market information, it is important to mention that the patent analysis was focused in thermoplastic elastomers along with styrene, butadiene and isoprene. This study covers two approaches: the market approach and the technological approach one. The market approach covers market information related to chemical industry and their key companies participating in the plastic segment. On the other hand, the technological approach refers to patent analysis of in thermoplastic elastomers along with styrene, butadiene and isoprene. It also covers statistical patent data regarding plastics and thermoplastic elastomers.

\section{a. Planning}

In this step was established the objective, time and resources. Matheo Patent was applied to develop the patent analysis.

$$
\begin{aligned}
& \text { Selection and gathering of } \\
& \text { information }
\end{aligned}
$$

In this study, first a general search was conducted on the topic of plastics in order to get an idea of the number of patents published in recent years. This general search was carried out by USPTO with the purpose of getting a high enough number of patents, to have an idea related to the progress in this field. Espacenet required much more time in the process of downloading (more than 20 hours). This can complicate the analysis process. The period selected was 2000-2012. The result was a total of 5446 patents, 6535 inventors, 2519 applicants, 445 IPC 4 digits (International Patent Classification) and 6132 IPC (full digits). The chronology of the patents, identified is shown in figure 2 .

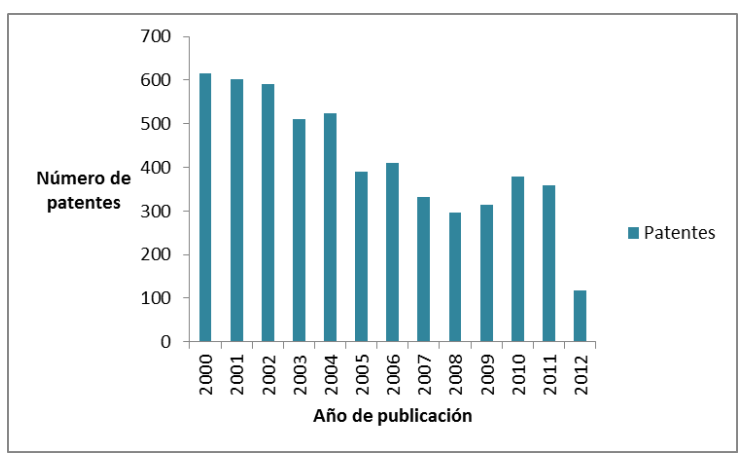

Figure 2. Chronology of patents issued about plastics, 2000-2012. Source: Data from USPTO and Matheo Patent.

A general search for thermoplastic elastomers was made with the same purpose using the USPTO database and taking into account the 2000-2012 period of time. The result was a total of 1531 patents, 2038 inventors, 2519 applicants, 223 IPC 4 digits and 1948 IPC full digits. The chronology of the patents is shown in figure 3 .

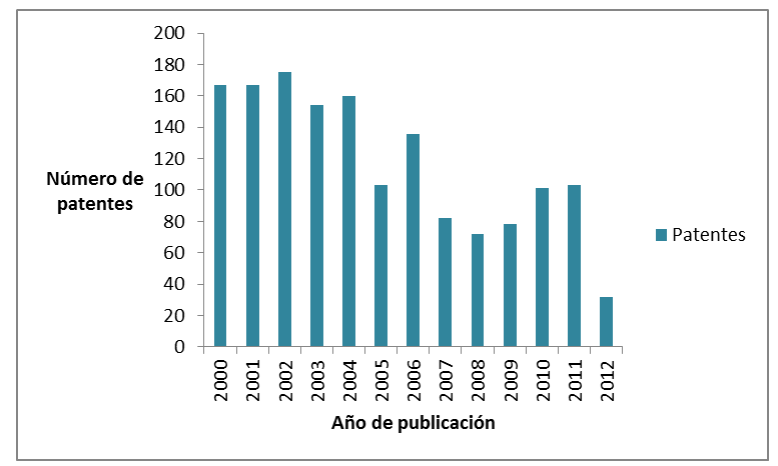

Figure 3. Chronology of patents issued about TPEs, 2000-2012. Source: Data from Espacenet and Matheo Patent. 
Subsequently, we made a research of patents on thermoplastic elastomers and styrene, butadiene and isoprene. The Espacenet database did not require a lot of time for downloading for this search. Using the database in the period 20002012 the result was a total of 477 patents, 811 inventors, 352 applicants, 68 IPC 4 digits and 507 IPC full digits.

The main IPC (4 digits) obtained was C08L which refers to Compositions of Macromolecular Compounds. However, in order to apply a deep analysis of the main applicants, a group was created from the applicants with the highest amount of patents (top 5). This group was integrated by the following organizations:

- Michelin Soc Tech

- Michelin Rech Tech

- Mitsuboshi Belting Ltd

- Toray Du Pont KK

- Polyone Corp

According to this group, there are different IPC 4 digits related to all applicants, where IPC C08L has the highest amount of patents. The IPC refers to Compositions of Macromolecular Compounds.

Regarding the IPC of full digits, all applicants are involved in the following, as shown in figure 4 .

\begin{tabular}{cc}
\hline \multicolumn{1}{c}{ IPC full digits } & \multicolumn{1}{c}{ Description } \\
\hline CO8L25/04 & Compositions of homopolymers or copolymers of \\
& compounds having one or more unsaturated aliphatic \\
& radicals, each having only one carbon-to-carbon \\
& double bond, and at least one being terminated by an \\
& aromatic carbocyclic ring; Compositions of \\
& derivatives of such polymers: Homopolymers or \\
& copolymers of styrene \\
CO8L53/02 & Compositions of block copolymers containing at least \\
& one sequence of a polymer obtained by reactions \\
& only involving carbon-to-carbon unsaturated bonds; \\
& Compositions of derivatives of such polymers: of \\
& vinyl aromatic monomers and conjugated dienes \\
\hline
\end{tabular}

Figure 4. Description of IPC full digits related to applicants involved. Source: Data from Espacenet and Matheo Patent.

A search regarding the keywords styrene, butadiene and isoprene in the abstract of the patents was then made. As a result we observed that the keyword styrene was related to 50 patents, butadiene to 15 patents and isoprene to 21 patents.
Moreover, all of these keywords were related among them to the following IPC (4 digits), as shown in figure 5.

\begin{tabular}{|c|c|}
\hline IPC 4 digits & Description \\
\hline COBL & $\begin{array}{l}\text { COMPOSITIONS OF MACROMOLECULAR COMPOUNDS } \\
\text { (pesticides, herbicides A01N; pharmaceuticals, cosmetics } \\
\text { A61K; explosives C06B; compositions based on polymerisable } \\
\text { monomers C08F, C08G; paints, inks, varnishes, dyes, polishes, } \\
\text { adhesives C09; lubricants C10M; detergents C110; artificial } \\
\text { filaments or fibres D01F; textile treating compositions D06) }\end{array}$ \\
\hline $\operatorname{cog} \mathrm{J}$ & $\begin{array}{l}\text { ADHESIVES; ADHESIVE PROCESSES IN GENERAL (NON- } \\
\text { MECHANICAL PART); ADHESIVE PROCESSES NOT } \\
\text { PROVIDED FOR ELSEWHERE; USE OF MATERIALS AS } \\
\text { ADHESIVES (surgical adhesives A61L 24/00; processes for } \\
\text { applying liquids or other fluent materials to surfaces in general } \\
\text { BO5D; adhesives on the basis of non specified organic } \\
\text { macromolecularcompounds used as bonding agents in layered } \\
\text { products B32B; organic macromolecular compounds C08; } \\
\text { production of multi-layer textile fabrics D06M 1700) }\end{array}$ \\
\hline COBK & $\begin{array}{l}\text { USE OF INORGANIC OR NON-MACROMOLECULAR } \\
\text { ORGANIC SUBSTANCES AS COMPOUNDING } \\
\text { INGREDIENTS (pesticides, herbicides A01N; pharmaceuticals, } \\
\text { cosmetics A61K; explosives C06B; paints, inks, varnishes, } \\
\text { dyes, polishes, adhesives CO9; lubricants C10M; detergents } \\
\text { C110; artificial filaments or fibres D01F; textile treating } \\
\text { compositions D06) }\end{array}$ \\
\hline
\end{tabular}

Figure 5. Description of IPC 4 digits related to keywords styrene, butadiene and isoprene. Source: Data from Espacenet and Matheo Patent.

\section{c. Analysis information \\ i. Market approach}

The global market for chemical products grew by $7.6 \%$ in 2010 to reach a value of USD \$ 706,312.5 million. The compound annual growth rate of the market in 2006-2010 was 3.3\% (Datamonitor, 2011).

This market is characterized by low product differentiation; the barriers to market entry are in addition the necessary capital to establish facilities and strict regulations that increase rivalry. In figure 6 , we can see the influential five forces on this problem.

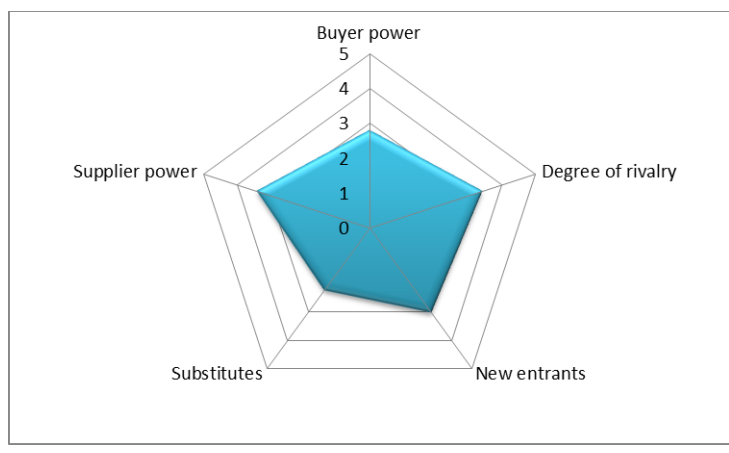

Figure 6. Five Forces driving the global market of chemical products. Source: Datamonitor, Global Specialty Chemical (2011) 
In the chemical industry there are several companies involved in the plastics sector, leading companies globally in this category are:

- BASF

- The Dow Chemical Company

- INEOS

- LyondellBasell Industries

Under this approach, information regarding the previous companies was gathered in order to apply the analysis of Porter's Five Forces, as shown in figure 7 .

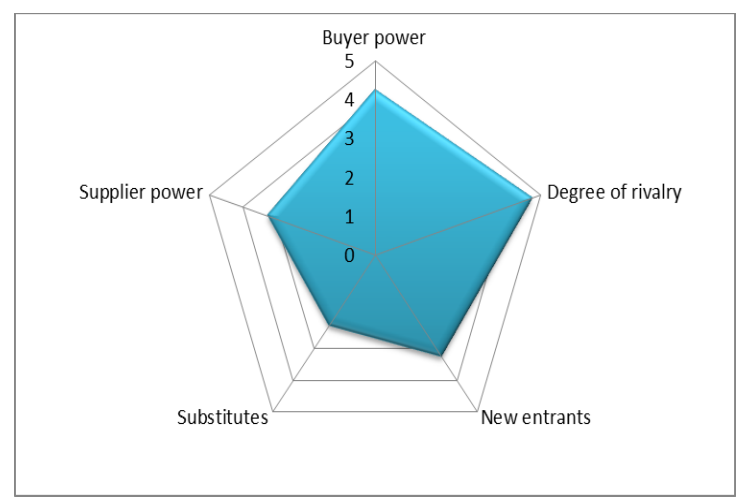

Figure 7. Five Forces of the main competitors driving the market of plastics.

According to figure 7, there is a strong rivalry between the companies in the plastics industry; the economies of scale contribute with the growth of the multinationals in this industry, followed by a considerable capacity of buyer power. The forces concerning the entry of new firms and the supplier power are considered moderate, as greater product differentiation between firms is required. In addition, there is a small threat of substitute products. Moreover, all of the companies analyzed have a strong activity in the area of polymers through their subsidiaries or business segments.

\section{ii. Technology approach}

The main applicants as well as the keywords: styrene, butadiene and isoprene; are linked to the IPC C08L (Compositions of macromolecular compounds). Based on this IPC analysis, four trends were identified. These trends are detailed with information related to the main applicants involved, amount of patents, abstract of some relevant patents, as follows:
Trend 1:

Compositions of block copolymers containing at least one sequence of a polymer obtained by reactions only involving carbon-to-carbon unsaturated bonds; Compositions of derivatives of such polymers: of vinyl aromatic monomers and conjugated dienes.

\begin{tabular}{|c|c|}
\hline Main applicantsinvolved & Amount of patents \\
\hline $\begin{array}{l}\text { Kurarary Co } \\
\text { Mitsuboshi Belting Ltd } \\
\text { Toray Du Pont KK } \\
\text { Michelin Rech Tech } \\
\text { Sumitomo Rubber Ind }\end{array}$ & C08L53/02 \\
\hline Number of patent & Abstract \\
\hline $\begin{array}{l}\text { W02011040586A1 } \\
\text { Thermoplastic elastomer } \\
\text { composition, molded article, } \\
\text { and sealing material for } \\
\text { medical use }\end{array}$ & 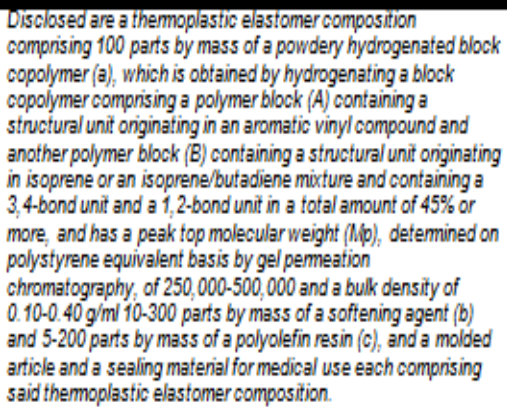 \\
\hline $\begin{array}{l}\text { W02010057611A1 } \\
\text { Novel copolymer with } \\
\text { thermoplastic elastomer } \\
\text { block, method for preparing } \\
\text { same and use thereof in an } \\
\text { elastomer composition }\end{array}$ & $\begin{array}{l}\text { The invention relates to a novel themoplastic elastomer of } \\
\text { block copolymer type that includes a linear or branched } \\
\text { elastomer block made of a polyisobutylene block (including } \\
\text { unsaturations) and at least one themoplastic styrene end block } \\
\text { The novel elastomer can advantageously be used in elastomer } \\
\text { composition for pneumatic objects, in particular for inner tight } \\
\text { gums for automobile tyres due to improved hysterefic } \\
\text { properties. }\end{array}$ \\
\hline $\begin{array}{l}\text { W02010074896A2 } \\
\text { Solvent bondable } \\
\text { thermoplastic elastomers }\end{array}$ & $\begin{array}{l}\text { An essentially halogen-free, plasticizer-free thempoplastic } \\
\text { elastomer compound is disclosed. The compound has from 10. } \\
80 \text { weight percent of a hydrogenated styrene butadiene } \\
\text { copolymer having a styrene content of less than } 20 \text { weight } \\
\text { percent from } 20 \text { - } 90 \text { weight percent of a polyolefin and less } \\
\text { than about } 3 \text { weight percent of antioxidant. The compound is } \\
\text { capable of being solvent bonded or welded to another } \\
\text { themmoplastic material using cyclohexanone alone or with } \\
\text { methyl ethyl ketone. The compound is especially useful as } \\
\text { medical tubing connected to other parts of medical equipment. } \\
\text { The bond strength of the compound to the other themoplastic } \\
\text { material is properly detemined only after multiple days of } \\
\text { bonding. }\end{array}$ \\
\hline
\end{tabular}

Figure 8. Description of elements related to trend 1.

Trend 2:

Compositions of homopolymers or copolymers of unsaturated aliphatic hydrocarbons having only one carbon-to-carbon double bond; Compositions of derivatives of such polymers, as illustrated in table below: 


\begin{tabular}{|c|c|}
\hline Main applicants involved & Amount of patents \\
\hline $\begin{array}{l}\text { Sumitomo Rubber Ind } \\
\text { Kurarary Co } \\
\text { Mitsubishi Chem Corp } \\
\text { Polyone Corp }\end{array}$ & $\mathrm{C} 08 \mathrm{~L} 23 / 00$ \\
\hline Number of patent & Abstract \\
\hline $\begin{array}{l}\text { US200317655 } \\
\text { Olefin thermoplastic } \\
\text { elastomer composition and } \\
\text { coated electric wire }\end{array}$ & $\begin{array}{l}\text { An olefin themoplastic elastomer composition (component (a)) } \\
\text { containing a dynamically crosslinked polyolefin thermoplastic } \\
\text { elastomer a polyolefin thermoplastic elastomer (component (b)) } \\
\text { at least one polymer (component (c)) selected from among an } \\
\text { ethylene copolymer, a hydrogenated styrene-butadiene rubber } \\
\text { having functional groups, a styrene elastomer modified with acid } \\
\text { anhydride, an ethylene-unsaturated carboxylic acid derivative } \\
\text { copolymer modified with the acid anhydride, ethylene-propylene } \\
\text { nubber modified with the acid anhydride, and polyethylene } \\
\text { modified with the acid anhydride and metal hydroxide } \\
\text { (component (d)). }\end{array}$ \\
\hline $\begin{array}{l}\text { JP2008045029A } \\
\text { Electroconductive } \\
\text { thermoplastic elastomer } \\
\text { composition, its } \\
\text { manufacturing method and } \\
\text { molded product }\end{array}$ & 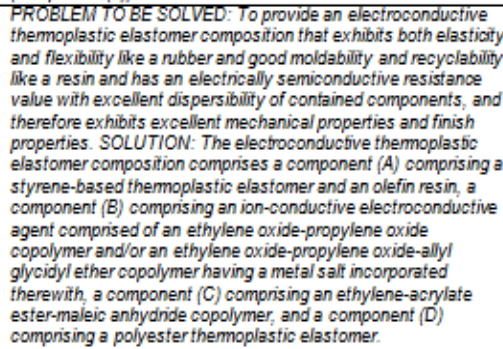 \\
\hline $\begin{array}{l}\text { W02009051060A1 } \\
\text { Thermoplastic elastomer } \\
\text { composition, and vibration- } \\
\text { proof sound-proof member } \\
\text { comprising the composition }\end{array}$ & $\begin{array}{l}\text { A themmoplastic elastomer composition which is excellent in a } \\
\text { vibration-proof property and a sound-proof property, and which } \\
\text { has flexibiuity, wear resistance and processability at the levels } \\
\text { required for a member (e.g., a roller) to be used in an image- } \\
\text { forming device (eg, a pniter). The themoplastic elastomer } \\
\text { composition contains a butyl nubber at a ratio of } 30 \text { to } 80 \text { mass } \% \\
\text { (inclusive), and further contains } 15 \text { to } 50 \text { parts by mass } \\
\text { (inclusive) of an olefin themoplastic resin and } 10 \text { to } 100 \text { parts } \\
\text { by mass (inclusive) of a hydrogenated styrene thermoplastic } \\
\text { elastomer relative to } 100 \text { parts by mass of the rubber } \\
\text { component, wherein the rubber component is finely dispersed } \\
\text { by dynamic cross-linking. }\end{array}$ \\
\hline
\end{tabular}

Figure 9. Description of elements related to trend 2.

Trend 3:

Compositions of oils, fats or waxes; Compositions of derivatives thereof, as illustrated in table next:

\begin{tabular}{|c|c|}
\hline Main applicants involved & Amount of patents \\
\hline $\begin{array}{l}\text { Mitsuboshi Belting Ltd } \\
\text { Sumitomo Rubber Ind } \\
\text { Polyone Corp }\end{array}$ & C08L91/00 \\
\hline Number of patent & Abstract \\
\hline W02011140381A2 & At themoplastic elastomer (IFt) compound is disclosed which \\
\hline $\begin{array}{l}\text { Super-soft thermoplastic } \\
\text { elastomers }\end{array}$ & $\begin{array}{l}\text { porous styrene block copolymer themoplastic elastomer of a } \\
\text { molecular weight greater than } 200,000 \text { and plasticizer oil of a } \\
\text { molecular wejght less than } 400 \text { present in an amount between } \\
85 \text { and } 91 \text { weight percent. Super-soff extruded or molded plastic } \\
\text { articles can be formed from pellets of the compound, with a } \\
\text { resulting Shore } 000 \text { Hardness of between } 45 \text { and } 60 \text {. Molded } \\
\text { articles can be prepared using hot melt adhesive dispensing } \\
\text { units. }\end{array}$ \\
\hline $\begin{array}{l}\text { KR20100075021A } \\
\text { Thermoplastic elastomer } \\
\text { composition havinglow } \\
\text { hardness }\end{array}$ & 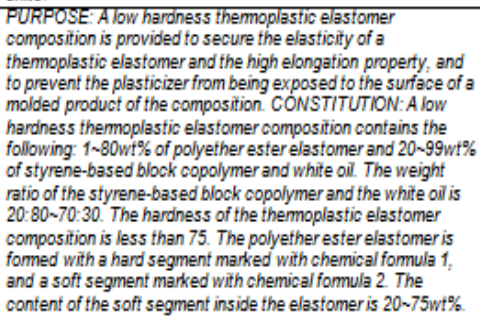 \\
\hline $\begin{array}{l}\text { KR20000022418A } \\
\text { High 1,2-content } \\
\text { thermoplastic elastomer oil } \\
\text { polyolefin composition }\end{array}$ & $\begin{array}{l}\text { PURPOSE: Themoplastic elastomenic composition is provided } \\
\text { to have greater softness, lower hardness, and improved melt } \\
\text { flow without an increase in the amount of oil. CONSTITUTION: } \\
\text { Thermoplastic elastomenic composition comprising: a base } \\
\text { composition comprising: (i) } 15 \text { to } 60 \text { weight percent of a block } \\
\text { copolymer having at least two polymenzed monovinyl aromatic } \\
\text { end blocks, each having a molecular weight of at least } 20,000 \text {, } \\
\text { and a mid block of hydrogenated polymenzed butadiene } \\
\text { wherein at least } 51 \text { mole percent of butadiene has polymenized } \\
\text { at the } 1,2 \text {-position, and wherein block copolymer has a } \\
\text { molecular weight of at least } 130,000 \text {, (ii) } 5 \text { to } 80 \text { weight percent } \\
\text { of a paraffinic oil, and (iii) } 5 \text { to } 25 \text { weight percent of a crystalline } \\
\text { polyolefin having a crystallinity of at least } 50 \% \text {. }\end{array}$ \\
\hline
\end{tabular}

Figure 10. Description of elements related to trend 3.

Trend 4:

Compositions of polyesters obtained by reactions forming a carboxylic ester link in the main chain; Compositions of derivatives of such polymers.

\begin{tabular}{|c|c|}
\hline Main applicants involved & IPC Full Digits \\
\hline $\begin{array}{l}\text { Toray Du Pont KK } \\
\text { Polyone Corp } \\
\text { Sumitomo Rubber Ind }\end{array}$ & C08L67/00 \\
\hline Number of patent & Abstract \\
\hline W02009155294A2 & A blend of themoplastic polyester elastomer, hydrogenated \\
\hline $\begin{array}{l}\text { Thermoplastic elastomers } \\
\text { exhibiting superiorabrasion } \\
\text { resistance properties }\end{array}$ & $\begin{array}{l}\text { block copolymer is disclosed which has good processability and } \\
\text { more effective abrasion resistance than the blend using } \\
\text { polystyrene in place of the high styrene content styrenic block } \\
\text { copolymer. }\end{array}$ \\
\hline $\begin{array}{l}\text { US6414081B1 } \\
\text { Compatibilized blends of } \\
\text { non-polar themoplastic } \\
\text { elastomers and polar } \\
\text { thermoplastic polymers }\end{array}$ & $\begin{array}{l}\text { The invention relates to compatibilized blends compisinga non- } \\
\text { polar thermoplastic elastomer, a polar themmoplastic polymer } \\
\text { selected from thermoplastic polyurethane (TPU), chloro } \\
\text { containing polymers, fluoro containing polymers, polyesters, } \\
\text { acrylonitnile-butadjene-styrene copolymers, styrene-acryonitnle } \\
\text { copolymers, styrene-maleic anhydride copolymer, polyacetal, } \\
\text { polycarbonate, polyphenylene oxide, anda suitable } \\
\text { compatibilizer. }\end{array}$ \\
\hline $\begin{array}{l}\text { KR20090066379A } \\
\text { Non-halogen flame } \\
\text { retardancy thermoplastic } \\
\text { polyester elastomer resin } \\
\text { composite }\end{array}$ & $\begin{array}{l}\text { A nonhalogenated flame retardant themmoplastic polyester } \\
\text { elastomer composite resin composition is provided to improve } \\
\text { environmental friendliness, to prevent flame dinpping and to } \\
\text { enhance heat resistance. A nonhalogenated flame retardant } \\
\text { thermoplastic polyester elastomer composite resin composition } \\
\text { comprises } 20 \sim 50 \text { weight\% of a themoplastic polyester } \\
\text { elastomer resin, } 5 \sim 50 \text { weight\% of a styrene-based elastomer, } \\
1 \sim 10 \text { weight\% of a reactive compatibiliser, } 10 \sim 50 \text { weight of } \\
\text { a melamine denvative as a flame refardant, and } 1 \sim 20 \text { weight\% } \\
\text { of an organic phosphate flame retardant. }\end{array}$ \\
\hline
\end{tabular}

Figure 11. Description of elements related to trend 4. 


\section{Conclusions}

Through the patent analysis it was possible to identify the main actors in the subject matter, as well as their areas of research. The trends were identified according the IPC C08L; this IPC was related to the main applicants (Michelin Soc Tech, Michelin Rech Tech, Mitsuboshi Belting Ltd, Toray Du Pont KK, Polyone Corp) and the keywords: styrene, butadiene and isoprene.

Our proposal provides results from both points of view of technology and the market; the results obtained can contribute in the future to identify opportunities. The method can be applied to any subject that considers patents as a source of strategic information.

The proposed method considers a global analysis on the plastics industry, covering both market information and the leading companies. The Analysis of Porter's five forces were incorporated into the stage of the analysis with good results.

\section{References}

Alegre, J.; Chiva, R.; Lapiedra, R. (2009) Measuring innovation in long product development cycle industries: an insight in biotechnology. Technology Analysis \& Strategic Management. Vol. 21, (4), 535-546

Datamonitor. (2011). Global Specialty Chemicals. Datamonitor Industry Profile.

Drobny, J. G. (2007). Handbook of Thermoplastic Elastomers. Norwich, New York, United States of America: William Andrew Publishing.

Escorsa, P., \& Rodríguez, M. (2000). La inteligencia tecnológica en la organización empresarial: Instrumento para la toma de decisiones. Revista de la Escuela de Economía y Negocios, II(4).

Feldman, D. (2008). Polymer history. Design monomers and polymers, 1-15.

Grande, J. (2008). TPEs Move Up the Performance Scale. Plastics Technology, 5373.

Kear, K. (2003). Developments in Thermoplastics Elastomers. Rapra Review Reports, XIV(10).
Lozano, I. (2003). El análisis de patentes en el mundo de la inteligencia tecnológica competitiva. PUZZLE(8).

Lugo Medina, J. N. (2008). Modelo de evaluación de tecnología basado en la conjunción de análisis de patentes y roadmapping (Tesis de maestría). Monterrey: ITESM.

Rodríguez, M. (2003). Análisis de patentes en la inteligencia competitiva y tecnológica: El caso de los materiales avanzados. PUZZLE, 4-9.

RTP. (2011). Retrieved November 2011 from http://www.rtpcompany.com/products/elastom er/index.htm

Schwarz, J. (2007). Competitive intelligence: A field for futurists? Future Research Quaterly.

SCIP. (2011). About SCIP. Retrieved January 2011 from Strategic and Competitive Intelligence Professionals: http://www.scip.org/content.cfm?itemnumber= 2214\&navItemNumber $=492$

Shih, M.-J., Liu, D.-R., \& Hsu, M.-L. (2010). Discovering competitive intelligence by mining changes in patent trends. Expert Systems with Applications, XXXVII(4). 